\title{
EFISIENSI EKSTERNAL PENDIDIKAN KEJURUAN DI KOTA YOGYAKARTA
}

\author{
${ }^{1}$ Irsan Roseno, 2Udik Budi Wibowo \\ 1SMK N 4 Sampit, 2Universitas Negeri Yogyakarta \\ 1J1. H.M. Arsyad, Mentawa Baru Hulu, Kotawaringin Timur, Kalimantan Tengah, Indonesia \\ 2Jl. Colombo No. 1, Depok, Sleman 55281, Yogyakarta \\ *Corresponding Author. Email: sanroseno@gmail.com
}

\begin{abstract}
Abstrak
Penelitian ini bertujuan mendeskripsikan efisiensi eksternal pendidikan Sekolah Menengah Kejuruan (SMK) di Kota Yogyakarta dengan sudut pandang nilai guna kemampuan lulusan. Penelitian ini menggunakan pendekatan kualitatif dengan jenis fenomenologi. Sumber data adalah dokumentasi dan informan dari alumni SMK di Kota Yogyakarta. Pengumpulan data dilakukan melalui studi dokumentasi dan wawancara. Teknik analisis data meliputi pengumpulan data, reduksi data, penyajian data, dan penarikan kesimpulan. Hasil penelitian menemukan keterserapan lulusan SMK di Kota Yogyakarta belum tercapai dengan maksimal. SMK belum mampu memberikan manfaat seperti yang diharapkan kepada seluruh lulusan. Oleh karena itu efisiensi eksternal pendidikan kejuruan di Kota Yogyakarta disimpulkan tidak efisien. Kesesuaian pengajaran di sekolah dengan perkembangan dunia kerja/industri belum sepenuhnya baik. Di sisi lain, terdapat beberapa manfaat dari pendidikan SMK bagi siswa antara lain: Mendapat pengalaman kerja melalui program Magang, PKL, atau prakerin; Mendapat peluang kerja di dunia usaha dan industri; Berwirausaha dengan keterampilan yang didapat; Pendidikan menengah kejuruan bisa melanjutkan ke jenjang pendidikan lebih tinggi. Sedangkan dari survai kepuasan diketahui alumni merasa puas terhadap lembaga sekolahnya. Namun terdapat beberapa informan yang merasa kurang puas antara lain kesesuaian kurikulum dengan dunia industri, keberadaan pembelajaran soft skill di lembaga pendidikan, bimbingan guru selama prakerin, jumlah kelengkapan sarana dan prasarana praktik, dan kesesuaian sarana prasarana praktik dengan dunia industri.
\end{abstract}

Kata kunci: efisiensi eksternal, pendidikan kejuruan

\section{THE EXTERNAL EFFICIENCY OF VOCATIONAL EDUCATION IN YOGYAKARTA}

\begin{abstract}
This research aims to describe of external efficiency of vocational education (SMK) in Yogyakarta with point of view of the values of graduates' ability. This research used the qualitative approach of phenomenology. The data sources were the documentation and the informants of graduates of Vocational High School in Yogyakarta. The data collection was done through document analysis and interview. The data analysis technique included of collecting data, data reduction, data display, and conclusion. The research finding reveals that the absorption of vocational high schools graduates in Yogyakarta have not been reached maximally. Vocational high schools cannot enable to give the benefits as expected for the graduates. So, the external efficiency of vocational education in Yogyakarta can be concluded that is inefficient. The instructional conformity of the school that related to the development of working field/industry is not good enough. In other hand, there are some benefits of Vocational education for students such as: getting experience in the work field through the internship program, PKL, or prakerin; getting job opportunity in the business world and industry; entrepreneurship with the skill that got; Vocational High School Education can continue to the advanced study. Meanwhile, based on the survey of satisfaction is known that the graduates feel satisfied toward their school education. However, there are some informan that are not satisfied with the conformity of curriculum related to the industry field, the existence of learning soft skill in the school education, the teacher's guide during prakerin, the number of completeness of practicum tools, and the conformity of practicum tools with the industry field.
\end{abstract} Keyword: external efficiency, vocational education

Permalink/DOI: http://dx.doi.org/10.21831/amp.v7i1.10558 


\section{Pendahuluan}

Proses pendidikan pada dasarnya bersumber dari masyarakat dan luarannya kembali kepada masyarakat. Pendidikan sebagai unsur utama penyiapan Sumber Daya Manusia (SDM) memegang peranan sangat penting dalam menentukan kualitas SDM. Pendidikan memengaruhi secara penuh pertumbuhan ekonomi suatu bangsa.

Schultz (1974) memperlihatkan bahwa pembangunan sektor pendidikan dengan manusia sebagai fokus intinya telah memberikan kontribusi langsung terhadap pertumbuhan ekonomi suatu negara, melalui peningkatan keterampilan dan kemampuan produksi dari tenaga kerja. Penelitian Hicks (1980) dan beberapa peneliti neoklasik lain menunjukkan pentingnya manusia yang terdidik untuk menunjang pertumbuhan ekonomi secara langsung bahkan seluruh sektor pembangunan makro lainnya. Dengan demikian titik singgung antara pendidikan dan pertumbuhan ekonomi terletak pada produktivitas tenaga kerja terdidik, dengan asumsi semakin tinggi mutu pendidikan semakin tinggi produktivitas kerja, dan pada gilirannya memengaruhi tingginya pertumbuhan ekonomi (Campbell \& Stanley, 1986). Memiliki pengetahuan dan keterampilan yang memadahi bukan saja dapat memiliki akses untuk mendapatkan suatu pekerjaan tertentu, melainkan juga memiliki peluang untuk dapat menciptakan lapangan pekerjaan baru. Berdasarkan pandangan tersebut investasi pendidikan dalam rangka meningkatkan mutu dan efisiensi merupakan langkah strategis untuk meningkatkan kualitas hidup masyarakat.

Beberapa studi Bank Dunia menunjukkan bahwa investasi pendidikan sebagai kegiatan inti pengembangan SDM terbukti telah memiliki sumbangan yang signifikan terhadap keuntungan ekonomi (W. W. McMahon, 1992). Temuan studi tersebut menyatakan bahwa keuntungan ekonomi (rate of return) investasi pendidikan lebih tinggi daripada investasi fisik dengan perbandingan rata-tata $15,3 \%$ dan $9,1 \%$. Hal ini menunjukkan bahwa investasi dalam pendidikan meng-untungkan baik dari segi sosial maupun ekonomis.
Mencermati amanat yang diberikan oleh Undang-Undang terhadap SMK bahwa paradigma pendidikan kejuruan menitikberatkan pada pendidikan yang menyesuaikan dengan permintaan pasar. Kebersambungan diantara pengguna lulusan pendidikan dan penyelenggara pendidikan menjadi dasar penyelenggaraan dan ukuran keberhasilan pendidikan kejuruan. Jelas bahwa pendidikan menengah kejuruan ditujukan untuk menyiapkan kebutuhan sumber daya manusia yang sesuai dengan kebutuhan masyarakat sehingga upaya-upaya yang dilakukan tidak menimbulkan permasalahan pengangguran baru.

Kenyataan saat ini memperlihatkan pendidikan di SMK jauh dari efisien. Hal ini disinyalir karena pemanfaatan sumber daya yang ada tidak menghasilkan lulusan seperti yang diharapkan. Pendidikan yang mereka peroleh tidak menjamin untuk mendapatkan pekerjaan sesuai dengan jenjang pendidikan yang mereka jalani. Kepala BPS, Suryamin menengarai belum adanya link and match antara pendidikan kejuruan dan permintaan industri menyebabkan lulusan SMK adalah yang paling banyak menganggur. Ketidaksesuaian ini tergambar dari hasil penelitian BPS yang di wartakan Sindonews, Februari 2014-Februari 2015 jumlah pengangguran di Indonesia meningkat 300 ribu orang, sehingga total mencapai 7,45 juta orang (Glienmourinsie, 2015). Data BPS menjabarkan tingkat Pengangguran Terbuka didominasi oleh penduduk SMK sebesar 9,05 persen, lalu disusul pada jenjang Sekolah Menengah Atas 8,17 persen, dan Diploma I/II/III sebesar 7,49 persen di periode Februari 2015.

Sedangkan di Daerah Istimewa Yogyakarta khususnya diwartakan Harian Jogja (6 Mei 2014) Tingkat pengangguran terbuka di DIY masih cukup tinggi kendati perekonomian di provinsi ini terus tumbuh membaik. Penyumbang terbesar angka tersebut merupakan lulusan universitas dan SMK (Anonym, 2014).

Perlu dipahami bahwa globalisasi saat ini melahirkan ukuran baru dan paradigma baru dalam memandang kualitas output pendidikan, yaitu dari outcome nya. 
Hal ini mengisyaratkan setiap bangsa wajib memiliki SDM handal, mempunyai daya juang tinggi dan mampu bersaing secara terbuka memperebutkan pekerjaan sesuai dengan kompetensi yang dimiliki. Kualitas SDM sangat penting karena kemakmuran suatu bangsa tidak hanya ditentukan oleh sumber daya alamnya melainkan kualitas sumber daya manusianya. Keunggulan SDM merupakan kunci menentukan siapa yang mampu menjaga kelangsungan hidup, perkembangan dan kemakmuran penduduknya dari segi nilai guna maupun ekonomi dalam persaingan era global.

Menteri Pendidikan Nasional Republik Indonesia (1996, pp. 20-21) menyatakan bahwa hasil pendidikan disebut berkualitas dari segi produk jika mempunyai salah satu atau lebih dari ciri-ciri berikut: pertama, peserta didik menunjukkan tingkat penguasaan terhadap tugas-tugas belajar (learning tasks) yang harus dikuasainya sesuai dengan tujuan dan sasaran pendidikan, diantaranya adalah hasil belajar akademik yang dinyatakan dalam prestasi belajar (kualitas internal); kedua, hasil pendidikan sesuai dengan kebutuhan peserta didik dalam kehidupannya sehingga dengan belajar peserta didik bukan hanya "mengetahui" sesuatu, melainkan "dapat melakukan sesuatu" yang fungsional untuk kehidupan-nya (learning and earning); ketiga, hasil pendidikan sesuai atau relevan dengan tuntutan lingkungan khususnya dunia kerja. Dari segi ini, maka relevansi merupakan salah satu aspek atau indikator dari kualitas.

Relevansi pada akhirnya memberikan dampak atau manfaat berkepanjangan terhadap luaran peserta didik. Bagi para ekonomi disebut sebagai efisiensi eksternal, yaitu mengacu pada sejauh mana sekolah mampu memproduksi outcome yang dikehendaki (McMahon, 2004, p. 7). Secara konseptual efisiensi eksternal dikaitkan dengan analisis keuntungan atas investasi pendidikan dari pembentukan kemampuan, sikap, keterampilan. Dalam memperhitungkan investasi tersebut ada dua manfaat penting, yaitu: menghasilkan kemampuan yang memiliki nilai ekonomi dan nilai guna dari kemampuan (Fattah \& Nurdin, 2007, p. 298). Suti
(2011) mengatakan faktor manfaat hasil dari pendidikan terdiri dari beberapa unsur; yaitu manfaat bagi stakeholder pendidikan, manfaat bagi pasar kerja dalam memenuhi SDM yang siap pakai, kompeten, dan bermutu, manfaat bagi instansi pendidikan sebagai bukti pencapaian reputasi yang positif, manfaat bagi daerah tersedia SDM yang lebih terdidik dan lain sebagainya

Penelitian Efisiensi eksternal pendidikan terlebih dahulu melihat banyaknya siswa yang diterima melanjutkan studi dan banyaknya siswa yang diterima di pasar kerja. Indikator utama yang biasa digunakan dalam mengidentifikasi derajat efisiensi eksternal adalah nilai guna dari keterserapan keluaran lembaga pendidikan oleh pasar kerja dan studi lanjut. Asumsi ceteris paribus dalam ilmu ekonomi digunakan untuk menyederhanakan beragam formulasi dan deskripsi dari berbagai anggapan. Beberapa faktor yang diketahui dan yang tidak diketahui yang dapat mempengaruhi hubungan keterserapan luaran pendidikan dianggap konstan. Faktor-faktor itu misalnya termasuk gejolak inflasi, krisis ekonomi, gejolak politik, dan sebagainya.

Berdasarkan latar belakang yang telah disampaikan, maka masalah yang ingin dipecahkan melalui penelitian ini adalah bagaimana efisiensi eksternal pendidikan SMK di Kota Yogyakarta. Oleh karena itu, penelitian ini bertujuan untuk mendeskripsikan efisiensi eksternal pendidikan SMK di Kota Yogyakarta dengan sudut pandang nilai guna kemampuan lulusan. Diharapkan penelitian ini menjadi masukan bagi stakeholders di wilayah terkait pada khususnya dalam rangka menyusun perencanaan pendidikan secara institusi dan regional, dalam rangka meningkatkan partisipasi DU/DI agar lulusan tertampung di dunia kerja, meningkatkan kompetensi kemandirian, dan nilai guna terhadap lulusan sehingga berkontribusi langsung terhadap produktivitas individu dan perkembangan/pertumbuhan wilayah.

\section{Metode Penelitian}

Penelitian ini dimaksudkan untuk mendeskripsikan efisiensi eksternal pendi- 
dikan kejuruan menggunakan pendekatan kualitatif fenomenologi. Penelitian berusaha memaknai efisiensi eksternal pendidikan kejuruan dengan melihat nilai guna dari lulusan SMK. Laporan ini didasarkan pada wawancara lapangan dengan para lulusan SMK di Kota Yogyakarta.

Penelitian ini dilaksanakan di Sekolah Menengah Kejuruan di Kota Yogyakarta dengan memilih tiga sekolah yaitu SMK SMTI Yogyakarta, SMK N 6 Yogyakarta, SMK Muhammadiyah 3 Yogyakarta. Penelitian berlangsung mulai bulan Januari sampai dengan Mei, 2016. Subjek penelitian adalah siswa lulusan/alumni ketiga SMK di Kota Yogyakarta. Data yang diambil berupa hasil wawancara terhadap siswa lulusan SMK dan data alumni SMK.

Teknik pengumpulan data menggunakan wawancara dan studi dokumentasi. Wawancara dilakukan untuk menggali informasi mengenai nilai guna yang diperoleh oleh alumni setelah lulus SMK. Studi dokumentasi berkaitan dengan data alumni untuk menelaah dan menghitung keseluruhan daftar siswa yang lulus, daftar siswa yang terserap di dunia kerja/dunia industri, daftar siswa yang terserap ke jenjang pendidikan lebih tinggi, dan daftar siswa yang tidak terserap atau tidak terlacak. Selain itu data alumni juga digunakan sebagai dasar pelacakan alumni yang dijadikan sumber informasi dalam proses wawancara. Instrumen yang dikembangkan adalah pedoman wawancara.

Teknik analisis data menggunakan model interaktif. Analisis interaktif dibagi menjadi tiga alur kegiatan yang bersamaan, yaitu reduksi data dari hasil wawancara. Kemudian dilanjutkan dengan penyajian, dan penarikan kesimpulan atau verifikasi.

\section{Hasil Penelitian dan Pembahasan}

Beberapa hal yang paling menonjol manfaat dari pendidikan kejuruan berdasarkan hasil wawancara dari alumni yang terseleksi ke dunia kerja dan studi lanjut: (1) Lulusan dari institusi ini dapat mengisi peluang kerja pada dunia usaha dan industri karena terkait dengan satu ijazah yang di- miliki oleh lulusannya melalui uji kompetensi. Dengan ijazah tersebut mereka memiliki peluang untuk bekerja; (2) Lulusan dari institusi ini bisa berwirausaha dengan keterampilan yang diperoleh di SMK sebagai pekerjaan sampingan selain pekerjaan pokok, atau sebaliknya; (3) SMK memberikan banyak pengalaman dalam bidang kerja melalui program kurikulum Magang, PKL, atau prakerin. (4) Lulusan pendidikan menengah kejuruan dapat melanjutkan ke jenjang pendidikan lebih tinggi sepanjang lulusan tersebut memenuhi persyaratan baik nilai maupun program studi atau jurusan sesuai dengan kriteria yang diisyaratkan.

Di sisi lain, berdasarkan survai kepuasan terhadap siswa yang terseleksi masuk ke dunia kerja dan studi lanjut dari penelitian ini bahwa SMK di Kota Yogyakarta sebenarnya memberikan layanan yang memuaskan, walaupun masih ada beberapa kekurangan. Terdapat beberapa responden yang memberikan nilai kurang puas pada beberapa poin pernyataan diantaranya adalah kesesuaian kurikulum dengan dunia industri, keberadaan pembelajaran soft skill di lembaga pendidikan, bimbingan guru selama prakerin, jumlah kelengkapan sarana dan prasarana praktik, dan kesesuaian sarana prasarana praktik dengan dunia industri.

Berdasarkan persentase data alumni yang diambil dari (tiga) SMK di Yogyakarta ditemukan keterserapan dari tiga SMK di Yogyakarta yang menjadi objek penelitian, bahwa dari 952 siswa lulus SMK di Kota Yogyakarta yang bekerja dan wiraswasta didapati berjumlah 57\%, kemudian yang melanjutkan pendidikan ke jenjang lebih tinggi $28,5 \%$. Sedangkan sisanya $14,5 \%$ ditemukan tertulis tidak bekerja, tidak terlacak dan lain-lain. Dengan jumlah hanya 57\% yang terserap ke dunia kerja dan dunia industri, maka bisa dikatakan bahwa lulusan SMK di Kota Yogyakarta dalam hubungannya dengan dunia kerja memang rendah. Ditambah lagi jumlah 14,5\% lulusan yang tidak bekerja tentu saja bukan merupakan jumlah yang sedikit. Hal ini menunjukkan pendidikan kejuruan yang selama ini dilaksanakan mempunyai disparitas yang mencolok antara kemampuan atau kompetensi yang 
diharapkan oleh dunia kerja dengan lulusan yang dihasilkan pendidikan kejuruan.

Hal ini terjadi karena tidak semua sekolah SMK mampu menyediakan lowongan bursa kerja bagi siswa aktif maupun alumninya. Sekolah lebih sekadar hanya mampu menyediakan tempat atau lokasi yang digunakan untuk membuka Job Fair kerja yang diperuntukkan untuk umum. Di sisi lain, seandainya sekolah memiliki hubungan dengan dunia industri dan membuka lowongan kerja yang dikhususkan buat siswa SMK yang bersangkutan, Lowongan yang ada di SMK tersebut tidak merata sehingga tidak ada keseimbangan yang memadai antara jurusan, lowongan, bahkan jumlah siswa dari SMK yang bersangkutan. Hal ini menyebabkan banyaknya siswa yang tidak tertampung untuk lowongan kerja.

Permasalahan lain adalah peralatan praktik yang sudah terlalu lama digunakan sehingga cenderung ketinggalan jaman bahkan sudah rusak parah. Salah satunya adalah kerusakan alat praktik bidang mesin atau otomotif. Alat praktik yang sudah terlalu lama dan terlalu sering digunakan untuk praktik dan sudah mengalami kerusakan sehingga tidak kondusif lagi untuk digunakan sebagai bahan praktik. Hal ini tentu saja menimbulkan kecanggungan dan menghambat optimalitas pembelajaran praktik terhadap siswa karena sekolah SMK adalah sekolah yang mengutamakan keterampilan dibandingkan dari sisi teori. Bagaimana siswa memiliki keterampilan yang diharapkan oleh dunia kerja dan industri apabila alat pembelajaran praktik sudah tidak layak digunakan bahkan ketinggalan jauh dari perkembangan industri.

Pemerintah meningkatkan komposisi jumlah SMK terhadap SMA menjadi 70\%:30\%. Dari tahun ke tahun pendidikan kejuruan (SMK) mengalami perkembangan dari sisi kuantitas yang diiringi dengan meningkatnya jumlah siswa. SMK berkembang menjadi lembaga kejuruan yang mempunyai peran sentral dalam penyediaan tenaga-tenaga yang terampil dan teknisi tingkat pertama. Sementara SMK belum seutuhnya mampu memberikan fasilitas peralatan dan bahan yang cukup untuk memenuhi standar kompetensi atau tujuan yang ditentukan kurikulum. Ditambah lagi ketersediaan dunia usaha dan dunia industri yang dijadikan tempat latihan (prakerin) tidak berbanding setara dengan semua jurusan yang ada di SMK. Sedangkan disampaikan oleh Pardjono (2011) bahwa sampai saat ini SMK menjadikan dunia usaha dan dunia industri sebagai tempat praktik siswa karena masih banyaknya SMK yang belum memiliki peralatan dan bahan yang cukup untuk memenuhi standar kompetensi atau tujuan yang ditentukan dalam kurikulum. Ini tentunya akan berdampak kepada kualitas lulusan SMK yang sebenarnya diharapkan dapat bekerja dan akan menjadi salah satu pendorong meningkatnya pertumbuhan ekonomi Negara.

Pemerintah seharusnya memberikan evaluasi secara aktif terhadap SMK di daerahnya masing-masing terhadap jurusanjurusan yang ada di SMK tersebut. Bukan berarti bahwa setiap SMK yang membuka jurusan baru dibiarkan begitu saja tanpa evaluasi yang berkelanjutan demi sebuah target jumlah SMK 70\%. Tugas dari sekolah bukan berhenti sampai siswa lulus sekolah. Akan tetapi bagaimana sekolah itu mampu menciptakan lulusan yang berkualitas sehingga bermanfaat bagi individu maupun masyarakat dan negara. Menurut Finch \& Crunkilton (1999) tujuan akhir kurikulum pendidikan kejuruan tidak hanya diukur melalui pencapaian prestasi berupa nilai tetapi melalui hasil dari pencapaian tersebut, yaitu hasil dalam bentuk unjuk kerja di dunia kerja. Dengan demikian, kurikulum pendidikan kejuruan berorientasi pada proses (berupa pengalaman-pengalaman dan kegiatan-kegiatan dalam lingkungan sekolah) dan produk (efek dari pengalamanpengalaman dan kegiatan-kegiatan tersebut pada lulusan). Menjamurnya SMK dan banyaknya program pendidikan baru yang dibuka harus diimbangi oleh kemampuan pemerintah dan sekolah untuk memberikan fasilitas yang dibutuhkan. Fasilitas tersebut adalah jaminan yang harus diberikan oleh sekolah dan pemerintah kepada siswa bahwa mereka mendapatkan guru yang mema- 
dai, peralatan praktik yang sesuai, lowongan pekerjaan yang memang sesuai dengan jurusan yang ada. Apabila evaluasi terhadap berdirinya SMK baru dan jurusan baru tidak dilakukan secara berkelanjutan dikhawatirkan menciptakan pengangguran-pengangguran baru yang menambah beban bagi daerah dan negara. Ketegasan pun harus diberikan dari pemerintah terhadap SMK yang tidak mampu lagi menjalankan roda pendidikan pada jurusan pendidikan di sekolahnya. Apabila didapati evaluasi terhadap jurusan tertentu ternyata lebih banyak menghasilkan pengangguran-pengangguran baru maka pemerintah harus segera mengambil tindakan pembenahan. Jika pembenahan yang dilakukan tidak bisa memberikan perubahan yang berarti maka lebih baik jurusan tersebut untuk ditutup tidak menerima siswa supaya tidak mengakibatkan atau menambahi jumlah pengangguran-pengangguran baru di masyarakat. Dalam konteks otonomi daerah, pengembangan pendidikan kejuruan memiliki peluang yang besar dan sangat strategis. Pemerintah daerah lebih memiliki hubungan yang dekat dengan penguasaha di daerahnya sehingga dapat membangun kerja sama yang baik dalam menciptakan tenaga kerja yang berasal dari SMK. Oleh karena itu evaluasi dan pengembangan SMK memerlukan kebijakan pemerintah dalam menyikapi hal ini, agar nantinya SMK benarbenar dapat menjadi pendukung utama dalam menyediakan tenaga kerja terampil sebagai salah satu penyokong pertumbuhan ekonomi bangsa.

SMK seharusnya memiliki inisiatif untuk menjalin hubungan komunikasi dan hubungan kerja sama dengan dunia industri. Hubungan kerja sama dan komunikasi ini guna menyeimbangkan SMK sebagai pemasok tenaga kerja terampil. Pihak dunia usaha dunia industri sebagai pemakai atau konsumen dari produk SMK yaitu lulusan. Menurut rekomendasi UNESCO (2001), pendidikan teknik dan kejuruan bagi orientasi pendidikan harus mencakup pembelajaran teori dan praktik yang seimbang. Selain itu pengelola program studi harus bekerja sama dengan para komunitas profe- sional di bidangnya. Proses pembelajaran di program studi hendaknya: (1) didasarkan pada pendekatan pemecahan masalah dan eksperimental dan melibatkan pengalaman dalam perencanaan metode dan pengambilan keputusan; (2) memperkenalkan pelajar untuk spektrum yang luas dari bidang teknologi dan situasi kerja yang produktif; (3) mengembangkan prosedur-prosedur khusus mengenai keterampilan praktis yang berharga seperti penggunaan alat, perbaikan dan prosedur pemeliharaan dan keselamatan, dan menghargai nilai kerja; (4) mengembangkan suatu apresiasi mengenai desain, pengerjaan dan kualitas yang baik; (5) mengembangkan kemampuan untuk berfungsi sebagai anggota tim dan berkomunikasi mengenai informasi teknis; (6) dekat dengan lingkungan setempat tanpa membatasi diri.

Dengan memperhatikan karakteristik SMK tersebut maka jaringan kemitraan antara SMK dengan dunia usaha/industri menjadi keniscayaan yang tidak dapat diabaikan. Peran industri semakin penting bagi SMK karena perkembangan teori pendidikan dan pembelajaran kejuruan lebih banyak menempatkan DUDI sebagai tempat belajar cara kerja yang efektif. Ada dua teori belajar di tempat kerja yang pokok yang terkait dengan DUDI, yaitu situated learning dan work-based learning (belajar berbasis tempat kerja). Kerja sama sekolah dan industri harus dibangun berdasarkan kemauan dan saling membutuhkan. Pihak dunia kerja dan industri seharusnya menyadari bahwa pihak industri tidak akan mendapatkan tenaga kerja siap pakai yang mereka perlukan dengan persyaratan yang dikehendaki, tanpa membangun program pendidikan bersama.

Perencanaan pendidikan merupakan penerapan rasionalitas serta analisis pada proses pengembangan pendidikan dengan tujuan pendidikan lebih efektif dan efisien (Permana \& Sukoco, 2017, p. 205). Perencanaan kurikulum dan praktik bisa disusun dengan pihak industri. Pembelajaran teoretis dan praktis digabungkan sedemikian rupa sehingga kesesuainnya terjamin. Para siswa di pendidikan kejuruan belajar keterampilan yang sebenarnya di dunia praktis, 
dan mempelajari dan merefleksikanya dalam dunia teoretis. Pada pendidikan kejuruan baik teori maupun praktik memiliki nilai yang sama untuk pembelajaran di sekolah dan belajar di tempat kerja. Dengan demikian, baik pembelajaran teori maupun praktik tidak terbatas pada tempat belajar siswa (Directorate-General for Education and Culture, 2006).

Di sisi lain, sekolah idealnya memiliki kontrak kerja sama atau integrasi untuk memberikan lowongan atau tempat bekerja bagi lulusan SMK-nya sehingga siswa bisa melakukan seleksi secara terpisah di sekolah masing-masing. Hal ini guna mengurangi tingkat persaingan yang tinggi dibandingkan bila lowongan pekerjaan itu dibuka secara umum. Sebab bila dibuka secara umum maka lulusan SMK berhadapan dengan siswa alumni SMA. Realita yang ada ditemui bahwa seleksi dalam penerimaan tenaga lebih ke arah Tes tertulis atau tes soal secara teoretis. Disampaikan oleh Bojonegoro (2016) bahwa hasil survei yang mengemuka bahwa perusahaan lebih memilih lulusan SMA dari lulusan SMK. Perusahaan lebih memilih mereka yang siap latih karena dinamika pekerjaan yang demikian cepat dalam era persaingan global sehingga memerlukan calon pekerja yang adaptif mampu mengikuti perkembangan. Oleh sebab itu SMK benar-benar harus mampu melakukan kerja sama, komu-nikasi, dan integrasi dengan pihak industri untuk meningkatkan link and match seperti yang diharapkan oleh kedua belah pihak agar cita-cita SMK bisa terwujud. SMK harus memberikan harapan dan prospek yang jelas terhadap siswa dengan keahlian yang diberikan.

Hasil pendidikan kejuruan harus menjadi tumpuan produktivitas perusahaan yang dicari banyak perusahaan. Untuk mencapai mutu SMK harus ada syarat bahwa untuk lulus SMK murid harus menempuh lulus ujian dalam kejuruannya. Ujian ini bisa dilakukan atau diintegrasikan dengan Asosiasi Profesi bersangkutan (sebagai anggota Kamar Dagang dan Industri, KADIN) bersama pemerintah pusat. Maka ujian ini dapat disamakan dengan Ujian $\mathrm{Na}-$ sional bagi murid SMA. Hasilnya lulusan
SMK mendapat satu ijazah atau certificate yang dikeluarkan Asosiasi profesi tersebut. Dengan ijazah tersebut lulusan SMK dapat diterima perusahaan yang memerlukan keahliannya dimana saja, bahkan di luar Indonesia kalau Asosiasi Profesi merupakan anggota Asosiasi Profesi Internasional atau ASEAN.

Untuk memperoleh SDM yang berkualitas dan memiliki daya saing, perlu didukung oleh suatu sistem pendidikan dan pelatihan yang dikembangkan berdasar pada kebutuhan pasar kerja dan dinamika percepatan perubahan yang terjadi pada dunia usaha dan dunia industri. Jangan sampai lowongan pekerjaan yang disediakan oleh sekolah malah menjadi momok yang menakutkan bagi siswa karena syarat seleksi dipandang terlalu berat oleh siswa dan menjadi sia-sia. Relevansi sangat diperlukan guna menghasilkan efisiensi eksternal pendidikan. UNESCO (2012, p. 38) mengevaluasi efisiensi eksternal pendidikan terdiri dalam menilai relevansi output dalam kaitannya dengan kebutuhan ekonomi dan masyarakat pada umumnya. Oleh sebab itu hubungan antara pelatihan dan pekerjaan sangat diperlukan.

Semua SMK dimotifasi dan didorong untuk mendidik dan membentuk muridnya sesuai dengan syarat-syarat yang diletakkan Asosiasi Profesi. Memiliki ijazah Asosiasi Profesi berarti jaminan mendapat pekerjaan yang sesuai dengan kecakapan serta mendapatkan penghasilan yang memadai. Makin banyak lulusannya memenuhi tuntutan itu, makin tinggi penilaian umum terhadap SMK tersebut. Pendidikan SMK yang menitikberatkan pada pembentukan kecakapan kejuruan tidak boleh mengabaikan hal-hal yang pada umumnya diperlukan seorang untuk bekerja baik.

Di sisi lain pendidikan SMK tidak boleh mengesampingkan komplemen penting yang mendukung kompetensi dari pendidikan SMK yaitu Soft skill. Memasuki era globalisasi perdagangan bebas sekarang ini banyak paradigma baru bermunculan dan memerlukan pertimbangan serta perhatian yang seksama. Lingkungan bisnis global akan menjadi semakin kompleks, dinamis, 
dan bermunculan berbagai konflik kepentingan. Hard skills seperti pemahaman tentang bidang pekerjaan fungsional atau area tertentu, tidak lagi mencukupi bagi seorang dalam meraih kesuksesan di dunia kerja. Saat ini diperlukan juga seseorang yang dididik secara liberal, memiliki pemikiran yang terintegrasi, komunikator yang handal, cerdas emosional, mampu bekerja dalam team dan beretika, yang semuanya itu bersifat soft skills. Pendidikan tradisional yang menekankan bahwa dalam bekerja, seseorang harus memiliki pengetahuan yang tinggi tentang bidang pekerjaannya saja, sekarang tidak lagi mencukupi.

Hasil kajian menunjukkan bahwa aspek-aspek kompetensi yang dirasa penting oleh industri adalah: kejujuran, etos kerja, tanggung jawab, disiplin, menerapkan prinsip-prinsip keselamatan dan kesehatan kerja, inisiatif, dan kreatifitas. Jelas bahwa dilihat dari sisi kompetensi maupun skill yang dibutuhkan, soft skills memiliki peran kunci dalam menentukan kualifikasi yang dibutuhkan industri. Urutan kompetensi utama yang dibutuhkan industri meliputi urutan: Jujur, Disiplin, Komunikasi, Kerja sama, dan Penguasaan Bidang Studi. Terlebih lagi di kalangan praktisi SDM, pendekatan hard skills sudah mulai ditinggalkan. Menjadi tidak bermakna jika hard skills-nya bagus, tetapi soft skills-nya buruk. Hal ini bisa dilihat pada iklan-iklan lowongan kerja berbagai perusahaan yang juga mensyaratkan kemampuan soft skills, seperti team work, kemampuan komunikasi, dan interpersonal relationship dalam seleksi penerimaan karyawannya. Saat penerimaan karyawan, perusahaan cenderung memilih calon yang memiliki kepribadian lebih baik meskipun hard skills-nya lebih rendah. Alasannya sederhana: memberikan pelatihan keterampilan jauh lebih mudah daripada pembentukan karakter.

Soft skills memiliki peran strategis dalam menentukan kesuksesan seseorang di dalam pekerjaannya. Oleh karenanya integrasi hard skills dan soft skills dalam penyiapan tenaga kerja dengan berbagai upayanya termasuk pendidikan formal harus dilakukan. Namun demikian dalam kenyataannya banyak lembaga pendidikan termasuk SMK yang belum menyadari pentingnya hal tersebut. Penelitian yang dilakukan the Business Higher-Education Forum dan the Collegiate Employment Research Institute at Michigan State University menunjukkan respon dari para manajer yang menyatakan bahwa siswa memiliki kemampuan teknis namun lemah dalam hal "soft skills".

Dengan alasan inilah SMK merupakan lembaga pendidikan yang mempersiapkan lulusannya untuk memiliki pengetahuan, keahlian, ketrampilan, soft skills yang akan menjadi bekal setelah menyelesaikan pendidikan. Sehingga lulusan SMK memiliki bekal sebagai job creator maupun sebagai worker, yang berarti siap memasuki pasar kerja.

Dengan demikian pertumbuhan perekonomian membutuhkan SMK sebagai lembaga yang menyiapkan specific human capital yang berkualitas. Dengan terciptanya SDM /lulusan yang berkualitas yaitu lulusan yang cerdas, terampil dan siap kerja sehingga siap memasuki pasar kerja. Keterserapan para lulusan yang merupakan output SMK akan meningkatkan produktivitas yang pada gilirannya akan meningkatkan pertumbuhan ekonomi melalui terciptanya nilai tambah terhadap barang dan jasa sekaligus meningkatkan tingkat partisipasi masyarakat dalam menyekolahkan anak-anaknya untuk menempuh studi di jenjang SMK. Semakin tinggi tingkat efisiensi eksternal lulusan dalam partisipasi di masyarakat, semakin tinggi pula kualitas SDM yang dapat digunakan dalam pengolahan sumber daya yang tersedia dalam perekonomian.

\section{Simpulan}

Berdasarkan pembahasan analisis data diperoleh kesimpulan keterserapan lulusan SMK di Kota Yogyakarta belum tercapai dengan maksimal. SMK belum mampu memberikan nilai guna seperti yang diharapkan kepada seluruh lulusan. Oleh karena itu efisiensi eksternal pendidikan kejuruan di Kota Yogyakarta disimpulkan tidak efisien. 
Kesesuaian pengajaran di sekolah berhubungan dengan perkembangan dunia kerja/industri disimpulkan belum sepenuhnya baik. Separuh lulusan dari tiga SMK yang menjadi objek penelitian tidak memperoleh pekerjaan formal. Artinya terjadi ketidaksesuaian antara keahlian yang dipelajari di SMK dan harapan dan kebutuhan perusahaan. Hal ini terjadi karena di dalam proses pengajaran, sekolah belum mampu menyediakan alat-alat praktik seperti yang diharapkan. Alat-alat praktik sudah terlalu lama digunakan sehingga sudah rusak parah dan ketinggalan teknologi juga jaman. Selain itu sekolah belum bisa sepenuhnya bekerja sama dengan dunia industri dalam menyediakan lowongan pekerjaan bagi siswa. Hal ini terlihat dari tidak meratanya lowongan pekerjaan untuk seluruh jurusan yang ada di sekolah. Sekolah hanya menambal dengan menyediakan tempat untuk digunakan sebagai Job Fair umum selama tiga hari.

Berdasarkan simpulan yang disampaikan tersebut, dapat disarankan sebagai berikut. Sekolah hendaknya melakukan survei mengenai efisiensi eksternal dari hasil lulusannya. Hasil survei tersebut paling tidak memberi gambaran mengenai sejauh mana manfaat yang diberikan sekolah terhadap siswa yang mengenyam pendidikan kejuruan di masing-masing sekolah. Efisiensi eksternal pendidikan kejuruan bisa dilihat dari sudut nilai guna yang diperoleh oleh siswa alumni.

Setelah melakukan survai efisiensi eksternal pendidikan, pihak sekolah selanjutnya merespon dengan melakukan evaluasi alat-alat praktik untuk melihat alat praktik masih layak digunakan atau tidak. Sekolah bisa berupaya menyediakan alatalat praktik seperti yang diharapkan. Alatalat praktik yang sudah terlalu lama digunakan sehingga sudah rusak parah dan ketinggalan teknologi juga jaman sebaiknya diganti dengan yang lebih baik. Dengan menyiapkan laboratorium, bengkel atau tempat praktik yang baik sesuai dengan program pendidikan masing-masing secara nyata maka siswa dapat berlatih secara teori dan praktik dengan optimal. Selain itu sekolah harus secara baik bekerja sama dengan dunia industri dalam menyediakan lowongan pekerjaan bagi siswa. Lowongan tersebut harus merata untuk seluruh jurusan yang ada di sekolah tersebut. Sesuai dengan Kebijakan pembangunan pendidikan nasional yang diarahkan untuk mewujudkan pendidikan yang berkeadilan, bermutu dan relevan dengan kebutuhan masyarakat. Diantaranya adalah tanpa adanya perbedaan layanan pendidikan ditinjau dari berbagai segi dan jaminan lulusan untuk melanjutkan dan keselarasan dengan dunia kerja. Selain itu sekolah harus senantiasa berusaha mendapatkan informasi sejauh mana keselarasan antara lulusan dengan dunia kerja yang ditunjukkan oleh dimensi kuantitas, kualitas/kompetensi, lokasi, waktu dan mengetahui problematika riil pemicu ketidakselarasan pendidikan dengan dunia kerja serta berusaha untuk mengatasi problematika tersebut.

\section{Daftar Pustaka}

Anonym. (2014). Mayoritas pengangguran DIY lulusan universitas dan SMK. Harian Jogja.

Bojonegoro, S. S. (2016). Revitalisasi pendidikan kejuruan. Kompas.

Campbell, R. M., \& Stanley, L. B. (1986). Contemporary labor economics. McGraw-Hill Book Company.

Directorate-General for Education and Culture. (2006). The economy of culture in Europe. Retrieved from http:/ / ec.europa.eu/assets/eac/cultu re/library/studies/culturaleconomy_en.pdf

Fattah, N., \& Nurdin, D. (2007). Ekonomi pendidikan: Ilmu dan aplikasi pendidikan. Bagian 2 ilmu pendidikan praktis. Tim pengembang ilmu pendidikan FIP-UPI. Bandung: PT Imperial Bakti Utama.

Finch, C. R., \& Crunkilton, J. R. (1999). Curriculum development in vocational and technical education: planning, content, and implementation (5th ed.). Boston: Allyn and Bacon. 
Glienmourinsie, D. (2015). Jumlah pengangguran bertambah jadi 7,45 juta orang. Sindonews.Com. Retrieved from

https:// ekbis.sindonews.com/read/9 97601/34/jumlah-pengangguranbertambah-jadi-745-juta-orang1430816593

Hicks, J. R. (1980). Preface and Manifesto. In K. J. Arrow \& T. Scitovsky (Eds.), Reading in welfare economic. London.

McMahon, W. W. (1992). Education and the economy: the external efficiency of education. (Budiono, Ed.). Jakarta: Pusat Informatika Balitbang Departemen Pendidikan dan Kebudayaan.

McMahon, W. W. (2004). Sistem informasi manajemen berbasis efisiensi. Jakarta: PT Logos Wacana Ilmu dan UNESCO.

Menteri Pendidikan Nasional Republik Indonesia. Peraturan Menteri Pendidikan Nasional Republik Indonesia Nomor 22 Tahun 1996 tentang Stndar Isi untuk Satuan Pendidikan Dasar dan Menengah (1996).

Pardjono. (2011). Peran industri dalam pengembangan SMK. In Workshop: peran industri dalam pengembangan SMK di SMKN 2 Kasihan Bantul.

Permana, P. S., \& Sukoco, S. (2017). Efektivitas manajemen praktik kerja industri di Sekolah Menengah Kejuruan Kota Yogyakarta. Jurnal Akuntabilitas Manajemen Pendidikan, 5(2), 199. https:// doi.org/10.21831/amp.v5i2.7 480

Schultz, T. (1974). The economic of the family. Chicago: Chicago of University Press.

Suti, M. (2011). Strategi peningkatan mutu di era otonomi pendidikan. Jurnal Medtek, 3(2). Retrieved from http://www.ftunm.net/medtek/Jurn al_MEDTEK_Vol.3_No.2_Oktober_20 11_pdf.

UNESCO. (2001). Technical and vocational education and training for the twentyfirst century: UNESCO and ILO recommendation. Paris: Section for Technical and Vocational.

UNESCO. (2012). Module 3 education sector diagnosis. Distance education programme on education sector planning. Paris: UNESCO. 